\title{
Indirect Governance at War: Delegation and Orchestration in Rebel Support
}

(C) The Author(s) 2021

Article reuse guidelines: sagepub.com/journals-permissions DOI: I0.| I /77/002200272 II0273 I I journals.sagepub.com/home/jcr

@SAGE

\section{Tim Heinkelmann-Wild' $\odot$, and Marius Mehrl' $\odot$}

\begin{abstract}
Instead of attacking their adversaries directly, states often do so indirectly by supporting rebel groups. While these support relationships vary considerably, existing research lacks a comprehensive account thereof. To explain states' choice of support, we suggest differentiating between two modes of support relationships according to the control opportunities they offer states over rebels: while delegation enables "hands-on" control, "hands-off" orchestration allows for plausible deniability and does not harm rebels' local legitimacy. We argue that sponsors prefer orchestration when "hands-on" control can be substituted by goal alignment or competition; and they prefer delegation when the conflict is highly salient. Tests using global data for the period 1975-2009 support the first two expectations. Surprisingly, states' capabilities also render "hands-off" orchestration more likely. The paper advances the understanding of external rebel support by transferring insights from indirect governance theory to the study of indirect wars and putting it to statistical test.
\end{abstract}

\section{Keywords}

proxy warfare, rebel support, principal-agent theory, orchestration, delegation, indirect governance, governor's dilemma.

\footnotetext{
'Geschwister Scholl Institute of Political Science, Ludwig-Maximilians-University Munich, Germany
}

\section{Corresponding Author:}

Tim Heinkelmann-Wild, Geschwister Scholl Institute of Political Science, Ludwig-Maximilians-University Munich, Oettingenstr. 67, Munich 80538, Germany.

Email: tim.heinkelmann-wild@gsi.Imu.de; tim.heinkelmann-wild@gsi.uni-muenchen.de 


\section{Introduction}

Rather than attacking other states directly, governments often rely on indirect warfare by supporting a rebel group's fight against an adversarial government (Salehyan 2010, 494). ${ }^{1}$ Take as examples the Russian government's support for the separatists in Eastern Ukrainian against their central government (Rauta 2016) as well as the United States (US) government's sponsorship of Kurdish rebels inter alia against the Assad government in Syria (Byman 2013, 906-7; Cragin 2015). Indeed, while direct war between states has become rare, the fight between factions within states has been the dominant type of conflict since 1945 (Melander, Pettersson, and Themnér 2016), with roughly half of rebel groups receiving external support by foreign governments (D. E. Cunningham, Gleditsch, and Salehyan 2013, 527; San-Akca 2017).

Research therefore increasingly focuses on indirect warfare (Byman 2005, 2013; San-Akca 2009; Bapat 2012; Belgioiso 2018; Sawyer, Cunningham, and Reed 2017; Karlén 2017; Tamm 2016; Petrova 2019; Krieg and Rickli 2019). A growing strand of this research draws on Principal Agent (PA) Theory and conceptualizes indirect warfare as "textbook example" (Hovil and Werker 2005, 25) of delegation, whereby "external actors play an important role in shaping the insurgency and exert control over it" (Salehyan 2010, 501; cf. Byman and Kreps 2010; Salehyan, Gleditsch, and Cunningham 2011; Salehyan, Siroky, and Wood 2014; Salehyan 2010; Szekely 2016; Popovic 2017; Rauta 2016). In a PA logic, sponsors should generally aim to supervise rebels' fulfilment of delegated tasks as strictly as possible to avoid agency slack. States are thus expected to "delegate to rebels [...] when they can effectively monitor agent activities and sanction bad behaviour" (Salehyan, Gleditsch, and Cunningham 2011, 711). The lack of such "hands-on" control is then explained by a sponsor's incapability to provide effective supervision and generally conceived as "weak and problematic" (Byman and Kreps 2010, 9; cf. Salehyan 2010, 505).

While this scholarship has advanced our understanding of indirect warfare considerably, it cannot fully account for the empirical variety of indirect warfare. In line with its expectations, we indeed observe instances where states closely control sponsored rebels. They thereby rely on "hands-on" control instruments such as the employment of troops on the ground to train the rebels or monitor their compliance, as well as the provision of sanctuaries on their own territory which allows for sanctioning rebels in case of non-compliance. For instance, the US retained a high degree of control through providing Syrian rebels with training and deploying military personnel on the ground (Byman 2013, 996). However, we also observe numerous instances where highly capable states refrained from using such "hands-on" control instruments. For example, Russia - a great power far from being militarily incapable - provided the rebels in East Ukraine with armaments without applying hierarchical controls (Rauta 2016, 97) and the US similarly mainly relied on financial aid to assist the Contras in Nicaragua (Hoekstra 2021). The question is thus: Why do state sponsors sometimes opt for "hands-on" controls when supporting rebel groups and refrain from them at other times? 
To solve this puzzle, this paper draws on and adds to the emerging literature on indirect governance (Abbott et al. 2016, 2020a, 2020b), and puts it to an empirical test in the realm of indirect warfare. We develop our theoretical argument in two steps. In a first step, we differentiate two modes of support relationships in indirect wars (second section): (i) delegation, where a sponsor can exert "hands-on" control over a rebel group; and (ii) orchestration, where a sponsor takes a "hands-off" approach and can only steer rebels by inducements. ${ }^{2}$ The sponsor's varying control over rebels results in specific benefits and limitations of the two modes. Delegation allows for the hierarchical control of rebels' compliance but constrains rebels' opportunity to build and preserve their local legitimacy — a valuable asset in indirect warfare-as well as sponsors' opportunity to plausibly deny their support, putting them at risk of domestic and international backlash. Orchestration, in turn, allows sponsors to profit from rebels' local legitimacy as well as plausible deniability but lacks the "hands-on" control instruments to enforce rebels' compliance. More control thus is not always better, but state sponsors face a trade-off when choosing between orchestration and delegation.

In the second step, we then theorize how this manifestation of the "governor's dilemma" (Abbott et al. 2020a, 2020b) shapes state sponsors' choice between orchestration and delegation (third section). We hypothesize that a sponsor willingly opts for "hands-off" orchestration when its downside - the lack of hierarchical control - can be alleviated by supporting a group with aligned goals, based on shared ethnic ties (goal alignment thesis), or a market mechanism, enabled through multiple rebel groups (supply thesis). On the contrary, a sponsor prefers "hands-on" delegation - and thus hierarchical control over a rebel group - , when the conflict is highly salient due to long-term rivalry with the target state (saliency thesis).

To test these hypotheses, we employ time-series cross-section logistic regression models with global data for the years 1975 to 2009 (fourth section). In line with our theoretical expectations, we find that sponsors are more likely to orchestrate a rebel group when they share common ethnic ties or when they can choose between multiple groups. In contrast, the evidence for sponsors opting for delegation when targeting long-term rivals is suggestive at best. Our results also yield important implications for future research (fifth section). In contrast to common assumptions in both the literature on indirect governance and rebel support, a sponsor's capabilities make delegation less - not more-likely and state sponsors' choice between orchestration and delegation remains remarkably stable - and not unstable - over time. The conclusion (sixth section) summarizes our contributions to the literatures on indirect governance as well as rebel support.

\section{Two Modes of Indirect Wars: Delegation and Orchestration}

To conceptualize the varieties of support relationships in indirect wars, we draw on the indirect governance framework (see Abbott et al. 2016, 2020a, 2020b) and differentiate between "hands-on" delegation and "hands-off" orchestration in rebel 
support. ${ }^{3}$ This enables us to structure important insights of the rebel support literature while going beyond its conceptual focus on delegation.

\section{Delegation}

In delegation relationships, sponsors use "hands-on" control instruments to ensure the rebels' compliance. When an external support relationship takes the mode of delegation, the sponsor can shape a rebel group in line with its goals or even create it in the first place; and the sponsor can use coercive means to ensure the rebels' compliance. State sponsors can exercise ex ante control by manipulating rebels' preference structure via socialization. They can influence the rebels' identities by subjecting rebel leaders to long training and indoctrination (see Salehyan 2010, 505; Byman and Kreps 2010, 10-11; see also, Hoover Green 2016). In addition, sponsors can rely on ex post control by supervising rebels' execution of delegated tasks and sanctioning potential slack (Byman and Kreps 2010, 10-12; Salehyan 2010, 502). A sponsor can send counselors to the rebels that closely monitor their behavior (and possibly also entail socializing effects). If rebels slack, the sponsor can use coercive force to compel them into compliance. It might (threaten to) remove its forces on the ground or expel rebels from safe havens on the sponsor's territory. Its threats of punishment are also more credible as the sponsor is aware of the rebels' location (Byman and Kreps 2010, 10-11; Salehyan 2010, 506). Overall, the sponsor is in a strong position as it can take away the provided support. While the sponsor might provide additional material or immaterial support, it is thus always able to use both carrots and sticks. Hence, if indirect warfare follows the logic of "hands-on" delegation, the sponsor provides training or sanctuaries for the insurgents, or military support using its own personnel on the ground. Take as an example the support relationship between Rwanda and the Rassemblement Congolais pour la Démocratie (RCD) in Congo-Kinshasa. The RCD relied on heavy material and troop support by Rwanda throughout its existence and operated under the supervision of the Rwandan army. This support resulted in the group achieving substantive military success in line with Rwandan goals (Reyntjens 2001; Tull 2003; Stearns 2013).

Delegation thus provides a sponsor with information about a rebel groups' fulfilment of the delegated tasks and means of sanction if this is not the case. Yet, hierarchical control also comes with limitations immanent to its visibility. "Hands-on" control of rebels allows for public responsibility attributions to the sponsor by international or domestic observers (see Schwarzenbeck 2017; Kruck 2020; Heinkelmann-Wild et al. 2021). Domestically, particularly in the case of atrocities and human losses, this might lead to protests and the punishment of the government in the voting booth (Mumford 2013). Internationally, this might trigger sanctions against this breach of international law or legitimate direct military retaliation by the targeted state and its allies. Furthermore, clearly visible foreign influence is often seen as illegitimate by the local population (Tamm 2020). A rebel group that is perceived as an agent of foreign interests might thus lose local 
legitimacy. This likely decreases the rebels' capacity to effectively fight the government (Salehyan 2010, 504, 506; Salehyan, Gleditsch, and Cunningham 2011, 713-14). Again, take as an example the support of the government of Rwanda to the RCD. The visible foreign involvement by Rwanda led to an international backlash against Kigali as well as the rebel group being perceived as an instrument of Rwandan occupation by most of the local population (Reyntjens 2001; Tull 2003; Stearns 2013).

\section{Orchestration}

In orchestration relationships, a sponsor enlists an autonomous rebel group by agreeing on the execution of certain tasks in return for their support. The sponsor does not shape rebels ex ante but enlists an independent rebel group that agrees on cooperating in return for support. The sponsor lacks "hands-on" control instruments and therefore can only nudge rebels in the preferred direction. In the absence of coercive means to compel rebels into compliance, a sponsor can only influence rebels ex post by means of conditionality. It can make demands in exchange for further strengthening rebels' operational abilities through material, financial, or informational support (see Byman and Kreps 2010, 10; Salehyan 2010, 506). Compared to delegation relationships, the sponsor is in a weaker position as it cannot take away the support once handed over even when rebels slack. In other words, the sponsor can only use carrots but lacks a stick. Moreover, the sponsor might not even be aware of rebels' slacking in the first place, as it cannot monitor their activities. In the absence of "hands-on" control, a sponsor can never be sure that rebels will act in line with its goals (see Byman and Kreps 2010, 6-8; Salehyan 2010, 495, 504). Thus, if indirect warfare follows the logic of "hands-off" orchestration, a sponsor solely provides material and/or immaterial support while refraining from hierarchical control instruments. Take as an example the support relationship between the Sudanese government and the rebels in its neighbor country South Sudan. The insurgents received less visible support in the form of weapons from Khartoum, allowing them to use local grievances for recruitment. The Sudanese government could deny any involvement while achieving its aim of distracting Juba from the dispute over the shared border (Small Arms Survey 2012; Todisco 2015).

In consequence, a sponsor can, firstly, tap into the benefits from rebels' local legitimacy among (parts of) the population that likely advances the war effort. A rebel group that is not under the hierarchical control of an external supporter is less likely perceived as an agent of foreign interests (see Salehyan 2010, 504, 506; Salehyan, Gleditsch, and Cunningham 2011, 713-14; Tamm 2020). ${ }^{4}$ Moreover, "hands-off" orchestration allows a sponsor to operate on the basis of plausible deniability. As rebels are more autonomous, sponsors can avoid responsibility attributions for, for example, human rights violations (see Schwarzenbeck 2017; Kruck 2020; Heinkelmann-Wild et al. 2021) and are in a better position to plausibly deny their involvement (see Heinkelmann-Wild and Zangl 2020). This diminishes the risk 
Table I. Two Modes of Indirect Warfare.

\begin{tabular}{|c|c|c|}
\hline & Delegation & Orchestration \\
\hline Mode & $\begin{array}{l}\text { "Hands-on" control due to training, } \\
\text { provision of sanctuaries, logistic or } \\
\text { military support }\end{array}$ & $\begin{array}{l}\text { "Hands-off" control due to purely } \\
\text { material or immaterial support } \\
\text { without attached controls }\end{array}$ \\
\hline Benefit & $\begin{array}{l}\text { Rebels' compliance due to monitoring } \\
\text { and sanctioning instruments }\end{array}$ & $\begin{array}{l}\text { Sponsors' plausible deniability and } \\
\text { rebels' intact local legitimacy due to } \\
\text { the lower visibility of the support } \\
\text { relationship }\end{array}$ \\
\hline Limitation & $\begin{array}{l}\text { Responsibility attribution to sponsors } \\
\text { and erosion of rebels' local legitimacy } \\
\text { due to the higher visibility of the } \\
\text { support types }\end{array}$ & $\begin{array}{l}\text { Rebels' non-compliance due to the lack } \\
\text { of monitoring and sanctioning } \\
\text { instruments }\end{array}$ \\
\hline
\end{tabular}

of both domestic and international backlashes (see Bapat 2012, 1-2; Borghard 2014, 7; Byman and Kreps 2010, 6, 9; Mumford 2013, 44; Salehyan 2010, 503-4; Salehyan, Gleditsch, and Cunningham 2011, 713). However, the lack of hierarchical control also comes with endogenous limitations. Orchestrators lack the instruments to warrant information about the rebels' actions and to sanction them if they use the received resources to engage in non-compliant behavior. For instance, rebels can sell their equipment or use the received resources for their own objectives that might contradict the sponsor's preferences (see Byman and Kreps 2010, 6-12; Salehyan 2010, 495, 504-6; Salehyan, Gleditsch, and Cunningham 2011, 714-15; Salehyan, Siroky, and Wood 2014, 638; Popovic 2017, 3-4; Rauta 2016, 93). The support relationship between Sudan and the South Soudanese rebels is again illustrative. The rebels used these weapons against Khartoum's goals by employing them not only against the government of South Sudan but also against opposing ethnic groups. Against the Sudanese government's objectives, this intensified communal strife in South Sudan (Small Arms Survey 2012; Todisco 2015). Table 1 summarizes orchestration and delegation as two modes of rebel support along with their specific benefits and limitations.

\section{Explaining State Sponsors' Choice between Orchestration and Delegation}

To explain why state sponsors opt for orchestration or delegation in indirect warfare, we start from the standard rational choice assumption that self-interested actors aim at maximizing their utility. As "hands-on" delegation and "hands-off" orchestration yield specific benefits and limitations, state sponsors are confronted with a trade-off when choosing between these two modes. The situation where a governor can either obtain hierarchical control over an intermediary or tap into specific benefits by refraining from control was coined as the "governor's dilemma" (Abbott et al. 
2020a, 2020b). Drawing on this recent research on indirect governance, we hold that state sponsors' choice between delegation and orchestration is shaped by the tradeoff between greater hierarchical control over rebels' compliance vs. benefits stemming from the rebels' relative independence, that is, local legitimacy and plausible deniability. We derive from this literature three independent variables that shape sponsors' cost-benefit calculation between the two modes of indirect warfare.

Firstly, selecting rebels with converging goals is a beneficial alternative to their hierarchical control (see Abbott et al. 2016, 2020a, 2020b). ${ }^{5}$ We expect a sponsor's fear of rebels' non-compliance to be significantly diminished by shared ethnic ties. While aligned goals between a rebel group and a sponsor might stem from a diversity of sources (Rauta 2018; San-Akca 2016), ethnic ties between a sponsor and a rebel group indicate shared or at least compatible goals in many conflict settings (see Saideman 1997, 2001, 2002; Maoz and San-Akca 2012; Cederman, Girardin, and Gleditsch 2009; Cederman et al. 2013; Salehyan 2010, 505; Byman and Kreps 2010, 5). Ethnic ties might also provide both parties with information about each other. They can thus substitute hierarchical monitoring instruments by serving as a base of mutual trust and cooperation (Habyarimana et al. 2007; Larson and Lewis 2017). As a result, ethnic ties can mitigate the risks of rebels' non-compliance given the lack of hierarchical controls. The Indian government's initial support for the Liberation Tigers of Tamil Eelam (LTTE) is illustrative of how shared ethnic ties can substitute the need for "hands-on" control. With India having its own Tamil population, the Indian government was committed to LTTE's goal of ending violence against the Tamils in Sri Lanka. At the beginning of the conflict, the Indian government only provided material and financial support (Groh 2010, 149, 170-1). Ethnic ties might thus substitute a sponsor's need of employing hierarchical "hands-on" controls and allow the sponsor to tap into the benefits provided by an independent rebel group and thus engage in "hands-off" orchestration.

Hypothesis 1: Sponsors are more likely to orchestrate when they share ethnic ties with a rebel group (goal alignment thesis).

Secondly, a sponsor values the benefits of orchestration over the benefits of delegation when "hands-on" controls can be substituted by a market mechanism (see Abbott et al. 2016, 2020a, 2020b; Biermann and Rittberger 2020). When a government has the choice to (potentially) support an alternative rebel group, the competition between multiple rebel groups provides a sponsor with extensive control in the absence of "hands-on" control instruments. ${ }^{6}$ When more than one group rebels against their government, they compete for the limited resources of the sponsor. Every rebel group therefore has an incentive to report their competitors' non-compliant behavior to the sponsor to gain an advantage. Furthermore, a sponsor's threats of withdrawing support as a sanction in case of non-compliance are more credible when alternative rebel groups are available since this renders a sponsor independent from a single group (Byman and Kreps 2010, 11). The case of the 
Syrian government supporting the Palestinian cause in the 1970s and 1980s illustrates how the competition between multiple rebel groups substitutes hierarchical controls by the sponsor. Syria was able to choose between competing Palestinian armed groups enabling them to counter non-compliance while it refrained from more "hands-on" control instruments on the ground. Moreover, Syria shifted its support between different groups as a sanction instrument and even pitted groups against each other to fuel competition (Byman 2005, 132-38). Competition between multiple rebel groups thus substitutes "hands-on" hierarchical controls by the sponsor, who can then tap into the benefits of "hands-off" orchestration.

Hypothesis 2: Sponsors are more likely to orchestrate when the number of rebel groups is high (supply thesis).

We expect a sponsor to enjoy the benefits of a looser, "hands-off" relationship with a rebel group when hierarchical "hands-on" control can be substituted by goal alignment or competition. However, we also agree with the existing literature on rebel support that the utility of "hands-on" delegation can outweigh the utility of "hands-off" orchestration. We, thirdly, posit that a sponsor values greater hierarchical control over the benefits of orchestration when the conflict is highly salient for it (Abbott et al. 2016, 726). This is the case when a strong rivalry exists between the sponsor and the targeted government (see Maoz and San-Akca 2012). When fighting a long-time rival, the achievement of the sponsor's strategic goals - independent of their concrete substance - might be too important to risk non-compliance by the rebels. Moreover, given a history of conflict with an adversary, plausible deniability might not be sustainable either way - and not even desirable in some cases. ${ }^{7}$ Rwandan support to the RCD illustrates how high conflict saliency between the support and the target state renders plausible deniability infeasible. The group's formation came shortly after strong friction between Kigali and the Congolese government it had helped put in power only months before, which resulted in Rwandan troops being expelled from the DRC. Rwanda had a strong interest in seeing its renegade ally toppled but also would have had a very hard time denying its involvement in any kind of uprising in the eastern DRC given the recent events (Stearns 2013). In highly salient conflicts, sponsors thus prefer "hands-on" control of rebels to enforce compliance over the benefits of "hands-off" orchestration.

Hypothesis 3: Sponsors are less likely to orchestrate when a strong rivalry exists between the sponsor and the target government (saliency thesis).

To sum up, we suggest three independent variables that shape a sponsor's choice between orchestration and delegation. We hypothesize that a sponsor values the hierarchical control enabled by "hands-on" delegation more than the benefits of orchestration when the conflict is highly salient for it. Conversely, a sponsor prefers to tap into the benefits of "hands-off" orchestration, that is, local legitimacy and plausible deniability, when hierarchical controls can be substituted by goal 
alignment, based on shared ethnic ties, or a market mechanism, enabled through the availability of multiple rebel groups.

\section{Researching Orchestration and Delegation in Indirect Wars}

To test our theoretical propositions, we employ the UCDP External Support Dataset. In line with our definition of indirect warfare as instances where a third-party government (i.e., the sponsor) intentionally supports a rebel group in its fight against its government (cf. Loveman 2002, 30; Salehyan 2010, 494; Mumford 2013,11), it includes information on the external sponsorship of warring parties, that is, "support that is actively given to strengthen the party in the particular conflict" (Högbladh, Pettersson, and Themnér 2011, 5). It covers the period 1975-2009 and indicates what specific types of support these parties received. We therefore chose the UCDP data over another recent dataset compiled by San-Akca (2016), whose wider definition of external support also comprises instances where a state unintentionally supports a rebel group which "manages to acquire these resources within [the state's] borders by its own means and efforts" (San-Akca 2016, 25). However, as San-Akca's Dangerous Companions Dataset covers more years, we use it to check the robustness of our results with an alternative data source and across an extended period.

Our dependent variable measures the occurrence of the two modes of support relationships in indirect wars: (i) delegation, where sponsors can hierarchically control the rebels by supervising the execution of delegated tasks on the ground; and (ii) orchestration, where sponsors lack "hands-on" control instruments but can nudge the rebels in the preferred direction by providing material, financial, or informational support. For the purpose of this paper, we relied on the provided support as an indicator for a sponsor's control opportunities. We code a dummy variable where delegation equals 0 and orchestration equals 1 based on the specific goods or services provided by state actors to a rebel group. We coded a year as orchestration when a sponsor only provided weapons, funding, intelligence, or "logistic goods" since hierarchical control over these goods is relinquished when handed over. We coded a year as delegation when at least one of the forms of support allows for a sponsor's hierarchical control. Support types featuring hierarchical control opportunities are the provision of troops, training, as well as access to the sponsor's territory (i.e., safe havens) or its military infrastructure. We hold each of these support forms sufficient to code the whole year as delegation. Thus, instances of delegation always comprise at least one of the support types listed above. Only in the absence of these support types, a year was coded as orchestration. Figure 1 summarizes the support types necessary for orchestration and those sufficient for delegation.

Taken together, we arrive at 391 distinct support-dyads and 1.502 instances in the years 1975 to 2009 where states supported rebel groups in another country either via orchestration or delegation ${ }^{9} ; 133$ support-dyads were continuously orchestrated, 218 


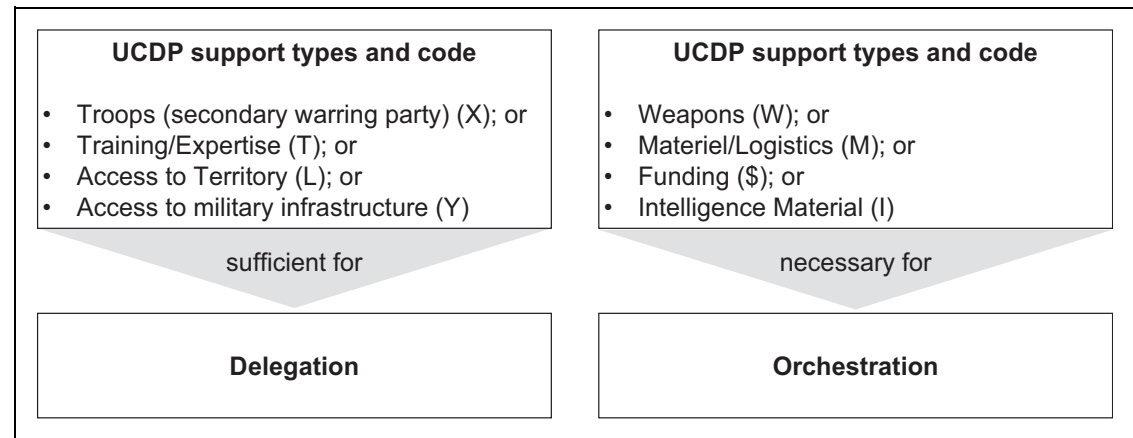

Figure I. Support types necessary for orchestration or sufficient for delegation. Note: We coded two dummy variables based on UCDP External Support Dataset; "unknown types" (O) and "other types" $(U)$ were coded as missing.

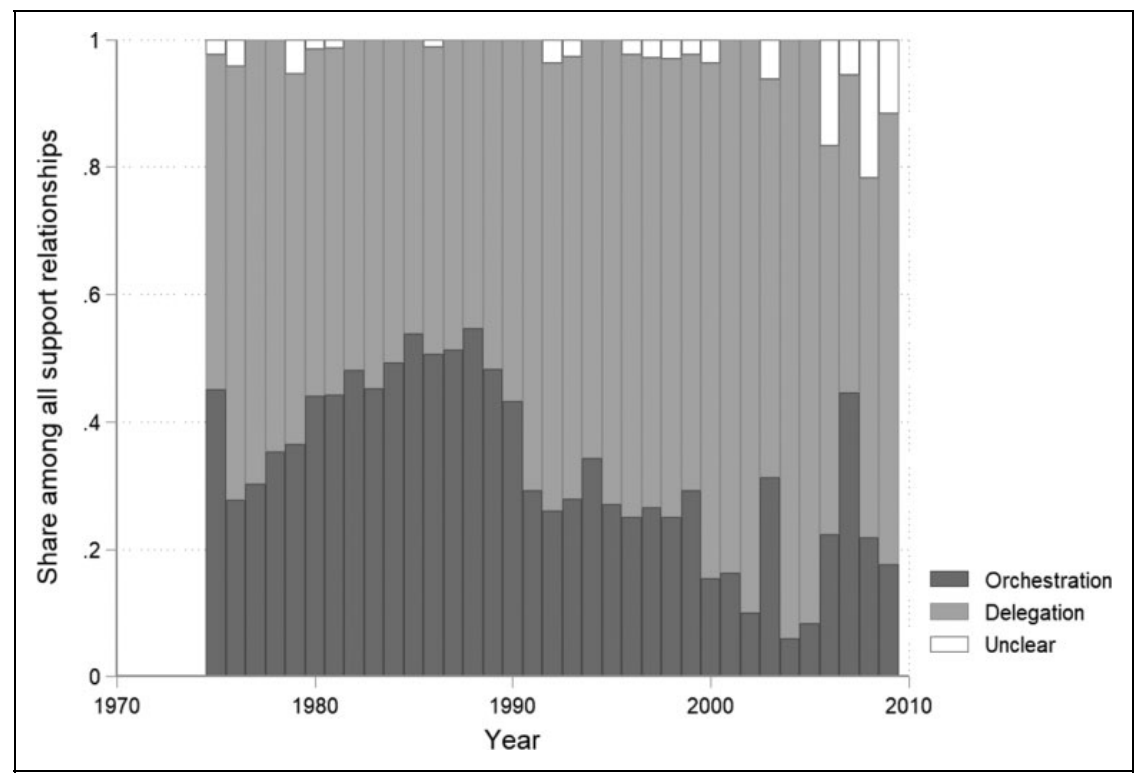

Figure 2. Support modes across time (1975-2009).

were continuously delegated, and forty experienced change in the support mode during the period of observation. Figure 2 shows that the share of orchestration varies considerably over time but became less prominent after the Cold War.

To understand why in some instances sponsors delegate whereas in others they orchestrate, we run a Time-Series Cross-Section (TSCS) logit analysis using the 
delegation-orchestration dummy as dependent variable. ${ }^{10}$ We operationalized the independent variables of our theoretical model as follows:

- Ethnic ties $\left(\mathbf{H}_{1}\right)$ : To measure ethnic ties, we rely on the Ethnic Power Relations data (Vogt et al. 2015). We first matched rebel groups to the ethnic groups they claim to fight for using the ACD2EPR data. Then, we identified the international kinship links of these groups and of those living in a sponsor using the TEK data. Finally, we used this information to create a dummy indicating whether the ethnic group a rebel group claims to fight for is also politically relevant in the sponsor state. The dummy takes the value 1 if such co-ethnicity exists and 0 if not.

- Number of rebel groups $\left(\mathbf{H}_{2}\right)$ : To count how many groups other than the supported one were fighting the target government in the previous year of the same armed conflict, we used the UCDP Dyadic Conflict Data (Harbom, Melander, and Wallensteen 2008; Allansson, Melander, and Themnér 2017).

- Rivalry $\left(\mathbf{H}_{3}\right)$ : For the existence of a rivalry, we used a dummy indicating whether the sponsor and target state were parties to a rivalry in the previous year, taken from version 5.20 of the rivalry dataset by Klein, Goertz, and Diehl (2006).

To account for the common claim that the lack of "hands-on" control in support relationships is due to the weakness of a sponsor, we also include measures of sponsors' capabilities. We examine two attributes, namely their financial as well as military endowments. Financial capabilities are measured using sponsors' GDP, taken from version 6.0 beta of the trade and GDP data by Gleditsch $(2002,2013)$. We measure military capabilities with their military expenditures taken from the Correlates of War (CoW) National Material Capabilities Data Version 5.0 (Singer, Bremer, and Stuckey 1972). To attenuate the influence of extreme values, we log both variables as is common in existing research.

We also control for several potential confounders that may reasonably affect the probability of orchestration while also being correlated with one or more of our main independent variables. First, we control for direct contiguity between the sponsor and target state as it should increase sponsors' ability to project power and thus to use hierarchical controls. We include a dummy indicating whether support and target state share a border, taken from Version 3.2 of the CoW Contiguity data (Stinnett et al. 2002). Second, the sponsor's regime type may play a role as democracies may be more concerned with atrocities in the conflict zone than autocracies (Salehyan, Siroky, and Wood 2014). We used the Polity IV data (Marshall, Gurr, and Jaggers 2016) to code a categorical indicator of a sponsor being autocratic (Polity score $\leq-7$ ), anocratic (Polity score $>-7$ and $<7$ ) or democratic (Polity score $\geq 7$ ) and included it as indicator variable with autocracy being the base category. Third, the sponsor's governmental capacity may also affect the support relationship (Borghard 2014, 68). More specifically, when the government of the sponsor fears a coup 
by its own military, this may affect whether it orders it to apply hierarchical controls on the supported rebel group (Tamm 2016). We thus included an indicator of coup risk in terms of civil-military relations based on Belkin and Schofer (2003), taking into account whether a country experienced a coup in the previous ten years, its regime legitimacy, and the strength of its civil society. Fourth, we included a dummy for post-1989 years as Figure 1 indicates that orchestration may have been more of a Cold War phenomenon. Finally, a rebel group's number of sponsors may affect the sponsors' choice of support mode as it affects the groups vulnerability toward sanctions (see also, Kruck 2020), leading us to include the number of sponsors as coded based on the UCDP External Support Data. ${ }^{11}$

\section{Empirical Analysis}

We test our hypotheses by running four main models (see Table 2). The dependent variable is a dummy indicating whether a support relationship takes the form of delegation or orchestration. We employ logistic regression models to examine its determinants. To account for time dependency, they include cubic polynomials of the time between the last orchestration event and the current observation.

Model 1 includes all variables discussed above but covers the shortest period of observation, 1975 to 2000. Model 2 extend this period to 2002 by excluding thepreviously insignificant-variable civil-military relations. Models 3 and 4 further increase the number of observations by respectively dropping the rivalry dummy and the lagged number of rebel groups. Please note that the number of observations is higher for Model 4 than Model 2 despite covering the same period. The reason is that Model 2 includes the lagged number of rebel groups as a predictor, resulting in all observations that occurred in the first year of a conflict being dropped as there is no such information about other rebel groups for them. As both Akaike's Information Criterion (AIC) and the Bayesian Information Criterion (BIC) exhibit the lowest values for Model $1^{12}$, we use it as our main model for computing substantive effect values.

The results corroborate our theoretical model. As expected, ethnic ties $\left(\mathrm{H}_{1}\right)$ between a sponsor and a receiving rebel group increase the likelihood of orchestration as the dummy has a positive and statistically significant effect in all four models. Also corresponding to our expectations, orchestration becomes more likely to occur as the number of groups $\left(\mathrm{H}_{2}\right)$ fighting in a conflict increases. This effect is again statistically significant in all models. The effect of rivalry $\left(\mathrm{H}_{3}\right)$ on orchestration is negative, but varies substantially in terms of its significance across models. Furthermore, we also find the effect of military capabilities to be stably significant. However, it turns out to be positive while the rebel support literature suggested a negative relationship: great capabilities of the sponsor make orchestration more likely. Regarding the control variables, only direct contiguity has a statistically significant effect which is negative. 
Table 2. Results of the Four Models.

\begin{tabular}{|c|c|c|c|c|}
\hline $\begin{array}{l}\text { Dependent Variable } \\
\text { Orchestration }\end{array}$ & $\begin{array}{c}(1) \\
1975-2000\end{array}$ & $\begin{array}{c}(2) \\
1975-2002\end{array}$ & $\begin{array}{c}(3) \\
1975-2009\end{array}$ & $\begin{array}{c}(4) \\
1975-2002\end{array}$ \\
\hline Ethnic Ties & $\begin{array}{l}1.490 * * * \\
(4.098)\end{array}$ & $\begin{array}{l}0.870^{* * *} \\
(2.356)\end{array}$ & $\begin{array}{l}0.725^{* *} \\
(2.182)\end{array}$ & $\begin{array}{l}0.757^{* * * *} \\
(2.701)\end{array}$ \\
\hline Number of Rebel Groups (lag) & $\begin{array}{l}0.172 * * \\
(2.442)\end{array}$ & $\begin{array}{l}0.166 \text { **** } \\
(2.803)\end{array}$ & $\begin{array}{l}0.138 * * \\
(2.428)\end{array}$ & \\
\hline Rivalry (lag) & $\begin{array}{l}-0.999 * * * \\
(-2.872)\end{array}$ & $\begin{array}{l}-0.572 * \\
(-1.811)\end{array}$ & & $\begin{array}{l}-0.476 * \\
(-1.732)\end{array}$ \\
\hline Military Expenditures (In) & $\begin{array}{l}0.392 * * \\
(2.359)\end{array}$ & $\begin{array}{l}0.394^{* * * *} \\
(2.784)\end{array}$ & $\begin{array}{l}0.371 * * * \\
(2.779)\end{array}$ & $\begin{array}{l}0.440 * * * \\
(3.693)\end{array}$ \\
\hline GDP (ln) & $\begin{array}{l}-0.032 \\
(-0.192)\end{array}$ & $\begin{array}{l}-0.150 \\
(-0.948)\end{array}$ & $\begin{array}{l}-0.141 \\
(-0.942)\end{array}$ & $\begin{array}{l}-0.184 \\
(-1.321)\end{array}$ \\
\hline Controls & & & & \\
\hline Two Sponsors & $\begin{array}{l}-0.645 \\
(-1.204)\end{array}$ & $\begin{array}{l}-0.480 \\
(-0.991)\end{array}$ & $\begin{array}{l}-0.645 \\
(-1.464)\end{array}$ & $\begin{array}{l}-0.131 \\
(-0.351)\end{array}$ \\
\hline Three or Four Sponsors & $\begin{array}{l}-0.132 \\
(-0.326)\end{array}$ & $\begin{array}{c}0.008 \\
(0.022)\end{array}$ & $\begin{array}{l}-0.153 \\
(-0.462)\end{array}$ & $\begin{array}{c}0.444 \\
(1.406)\end{array}$ \\
\hline More than Five Sponsors & $\begin{array}{c}0.094 \\
(0.235)\end{array}$ & $\begin{array}{l}-0.191 \\
(-0.504)\end{array}$ & $\begin{array}{l}-0.220 \\
(-0.623)\end{array}$ & $\begin{array}{c}0.278 \\
(0.854)\end{array}$ \\
\hline Shared Border & $\begin{array}{l}-0.798^{* * *} \\
(-2.312)\end{array}$ & $\begin{array}{l}-0.709 * * \\
(-1.998)\end{array}$ & $\begin{array}{l}-1.092^{* * *} \\
(-4.023)\end{array}$ & $\begin{array}{l}-0.602^{*} \\
(-1.955)\end{array}$ \\
\hline Sponsor: Anocracy & $\begin{array}{c}0.344 \\
(0.999)\end{array}$ & $\begin{array}{l}0.023 \\
(0.068)\end{array}$ & $\begin{array}{c}0.191 \\
(0.611)\end{array}$ & $\begin{array}{c}0.070 \\
(0.225)\end{array}$ \\
\hline Sponsor: Democracy & $\begin{array}{c}0.699 \\
(1.548)\end{array}$ & $\begin{array}{l}-0.178 \\
(-0.453)\end{array}$ & $\begin{array}{l}-0.318 \\
(-0.836)\end{array}$ & $\begin{array}{l}0.010 \\
(0.026)\end{array}$ \\
\hline Sponsor: Coup Risk & $\begin{array}{c}0.120 \\
(1.211)\end{array}$ & & & \\
\hline Post-1989 & $\begin{array}{l}0.815^{* * * *} \\
(2.811)\end{array}$ & $\begin{array}{l}0.165 \\
(0.615)\end{array}$ & $\begin{array}{c}0.076 \\
(0.3 \mid 2)\end{array}$ & $\begin{array}{l}0.137 \\
(0.584)\end{array}$ \\
\hline Years since Orchestration & $\begin{array}{l}-7.507^{* * * *} \\
(-7.237)\end{array}$ & $\begin{array}{l}-6.696 * * * \\
(-7.173)\end{array}$ & $\begin{array}{l}-7.057^{* * *} \\
(-7.595)\end{array}$ & $\begin{array}{l}-6.093^{* * * *} \\
(-6.636)\end{array}$ \\
\hline Years since Orchestration ${ }^{2}$ & $\begin{array}{l}1.818^{* * * *} \\
(5.861)\end{array}$ & $\begin{array}{l}1.649 \text { **** } \\
(5.688)\end{array}$ & $\begin{array}{l}1.741^{* * *} \\
(6.093)\end{array}$ & $\begin{array}{l}1.509 * * * \\
(5.346)\end{array}$ \\
\hline Years since Orchestration ${ }^{3}$ & $\begin{array}{l}-0.131^{* * *} \\
(-4.808)\end{array}$ & $\begin{array}{l}-0.122^{* * * *} \\
(-4.584)\end{array}$ & $\begin{array}{l}-0.129 * * * \\
(-4.953)\end{array}$ & $\begin{array}{l}-0.112^{* * * *} \\
(-4.384)\end{array}$ \\
\hline Constant & $\begin{array}{c}0.282 \\
(0.166)\end{array}$ & $\begin{array}{c}1.154 \\
(0.823)\end{array}$ & $\begin{array}{c}1.821 \\
(1.359)\end{array}$ & $\begin{array}{c}-0.037 \\
(-0.029)\end{array}$ \\
\hline $\begin{array}{l}\mathrm{AIC} \\
\mathrm{BIC}\end{array}$ & $\begin{array}{l}446.120 \\
524.931\end{array}$ & $\begin{array}{l}545.549 \\
621.302\end{array}$ & $\begin{array}{l}592.408 \\
664.741\end{array}$ & $\begin{array}{l}665.811 \\
739.017\end{array}$ \\
\hline Observations & 762 & 841 & 918 & 973 \\
\hline
\end{tabular}

Note: Logistic Regression estimates. Standard errors clustered on the support-dyad, z-statistics in parentheses.

$* p<0.1$.

$* * p<0.05$.

$* * * p<0.01$. 


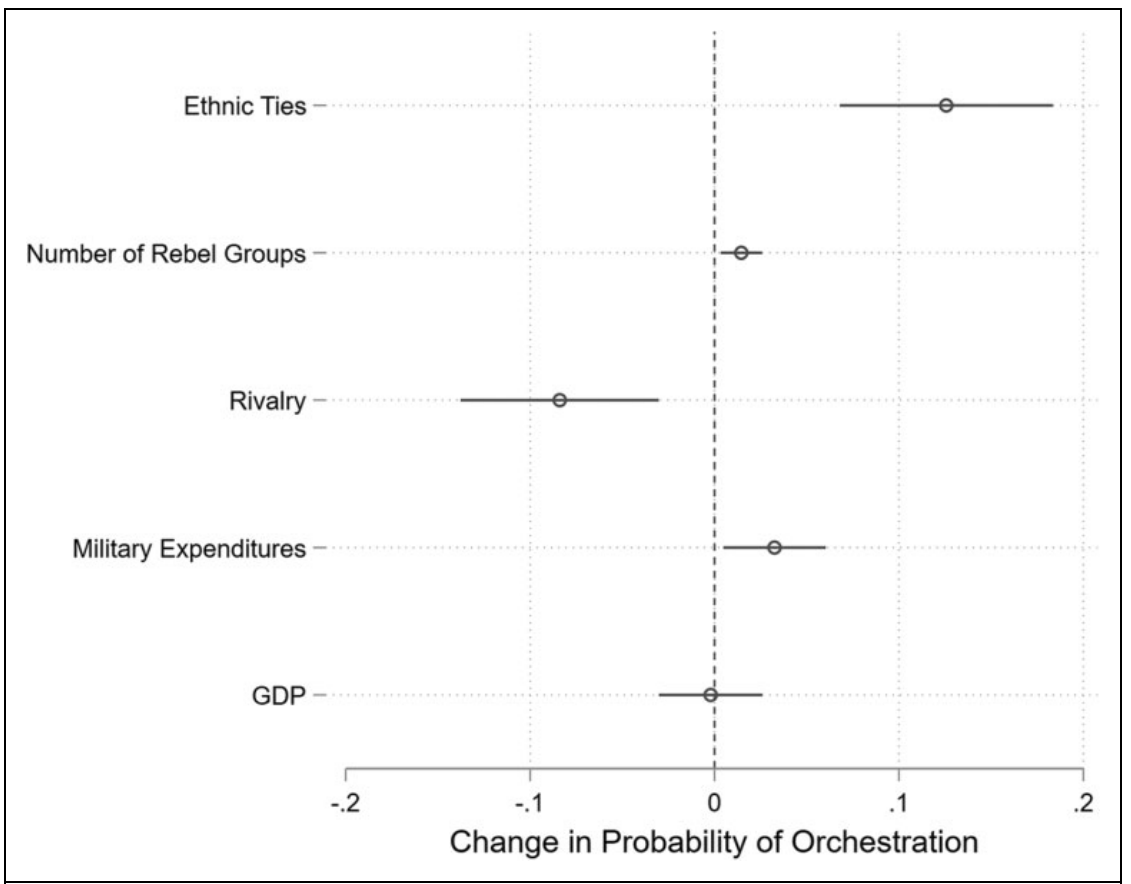

Figure 3. First estimates for model I. Note: Discrete first differences computed from Model I (95 percent $\mathrm{Cls}$ ) while holding all other variables at their observed values.

Before discussing the theoretical implications of these results, we explore the substantive effect the independent variables have on the choice of support type. We first compute first difference estimates for the variables of theoretical interest in Model 1 and present them graphically in Figure 3. These indicate the change in the predicted probability of orchestration given a one-unit change in the respective variable of interest with all other variables being at their observed values. This suggests that the strongest effect for a one-unit change is that of ethnic ties between the sponsor and rebels as their existence makes orchestration 12.6 percent more likely. ${ }^{13}$ In contrast, a rivalry between sponsor and target state decreases the likelihood of orchestration by 8.4 percent.

However, the number of rebel groups in a conflict and sponsors' military capabilities as measured by their military expenditures also have noticeable positive effects on orchestration. While a one-unit change only increases its probability by 1.4 percent and 3.3 percent, respectively, these are (semi-)continuous variables.

We thus graph the probability of orchestration over their respective full ranges in Figure 4. There, it becomes clear that a shift of their full range of empirical values is associated with an increase of 10.9 percent and almost 40.0 percent, respectively. However, confidence intervals for both variables are often 


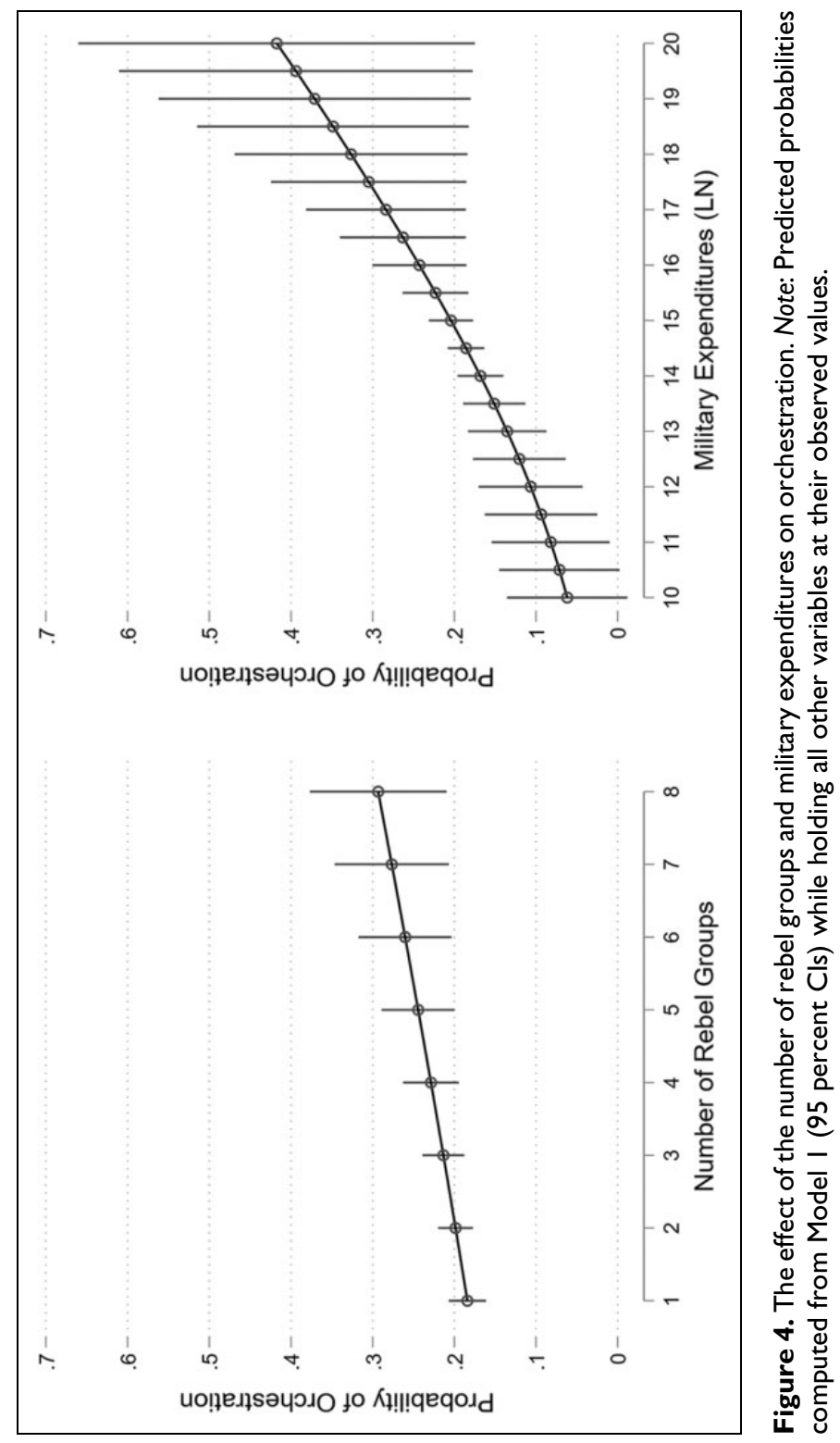


large due to few observations for a specific value, meaning that these point estimates are relatively imprecise.

To sum up, our results corroborate our expectation that ethnic ties between the sponsor and a rebel group, the number of rebel groups in a conflict, and a rivalry between sponsor and target state are all significantly related to the sponsor's chosen mode of support. This is also the case for the sponsor's capabilities. These significant relationships are substantively relevant as changes in all four variables are associated with substantial shifts in the likelihood of orchestration. Finally, we examine these variables' relevance in terms of our model's predictive out-ofsample performance by running a fourfold cross-validation exercise (see Ward, Greenhill, and Bakke 2010). Its results indicate that dropping any of the three theoretically relevant variables from the full model diminishes its predictive performance. $^{14}$

Our results are also generally robust to several additional tests. Most importantly, we address the potential selection stemming from the decision between orchestration and delegation being hardly independent from a state's decision on whether to provide support to a given group in the first place. For instance, ethnic ties or an international rivalry not only shape the type of support but also make the occurrence of a support relationship more likely in the first place (see Saideman 1997, 2002; Maoz and San-Akca 2012; Cederman, Girardin, and Gleditsch 2009; Saideman 2001). To tackle this, we first estimate selection models which model both the decision to support and the decision between delegation and orchestration as interlinked stages within the same model. While the second stage takes orchestration as the outcome variable and mirrors our main models in the choice of independent variables, the first stage has the occurrence of support as dependent variable and a parsimonious set of predictors previously shown to drive external sponsorship. We present the results of a selection model including the same independent variables as Model 1 in its second stage in Figure 5 and results tables for both this and additional models as well as a more detailed discussion of these specifications in the Online Appendix. The estimates mirror those of the main models, suggesting that selection does not drive our results.

In the Online Appendix, we also employ matching as an alternative strategy to address selection and again find results which are supportive of our expectations. We also conduct several additional robustness checks. Given that a sponsor supports more than one group in 30 percent of observations, we test how this affects our findings, specifically that outside options increase the probability of orchestration. Moreover, we examine whether the (co-)creation of a rebel group by a sponsor or different aggregations of the dependent variable impact our substantive results. Our findings remain unaffected. To check whether the choice of data source affects our results, we use the Dangerous Companions Dataset (San-Akca 2016) to replicate our results. While our theoretical model is generally supported by this exercise as the effects of ethnic ties and rivalry are in line with our expectations, the number of rebel groups does not achieve statistical significance. The results of these as well as 


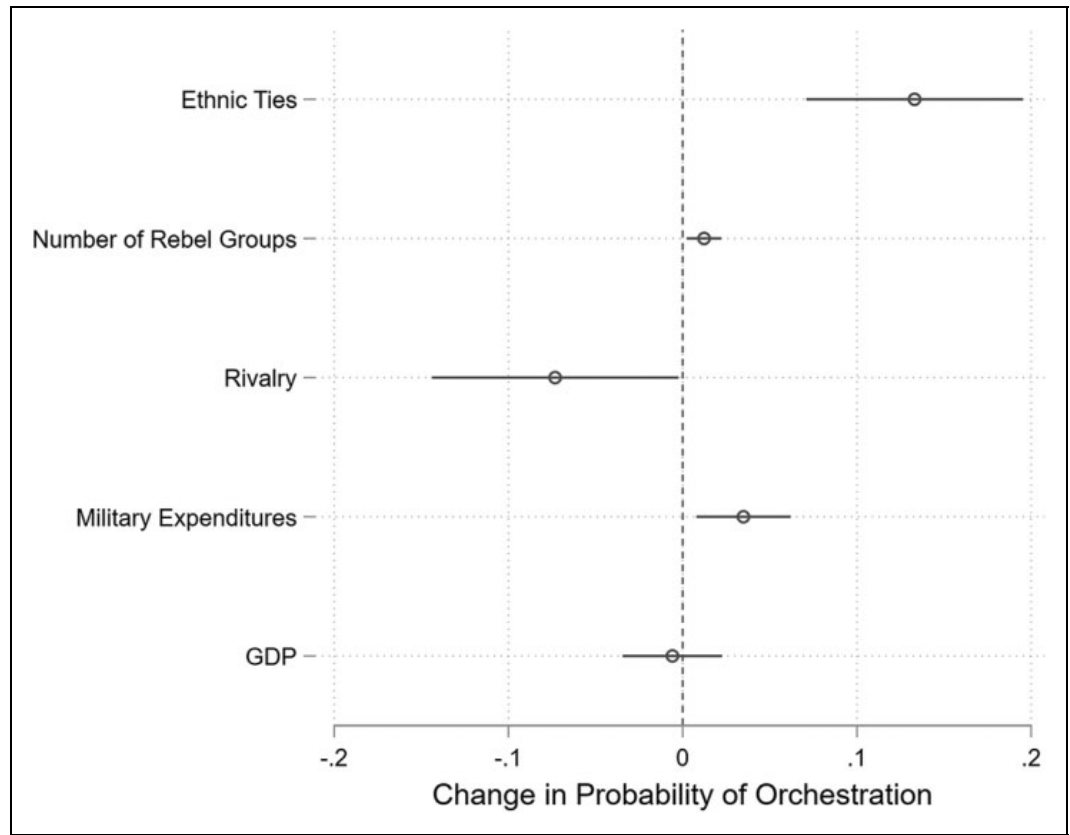

Figure 5. First difference estimates of selection model. Note: Discrete first differences computed from Online Appendix Model AI (95 percent Cls) while holding all other variables at their observed values.

further additional specifications are reported in the Online Appendix. Before we summarize our contributions, the next section turns to two results that have implications for scholarship on indirect warfare and indirect governance more generally and outlines avenues for future research.

\section{Theoretical Implications}

While the empirical analysis largely corroborated our theoretical model, two additional results also deserve particular consideration since these contradict recent scholarship on indirect governance and rebel support: the positive effect of sponsors' capabilities on the likelihood of orchestration; and the significant stability of sponsors' choice between orchestration and delegation. In the following, we shortly discuss these findings and offer preliminary interpretations that might provide a starting point for future studies.

Firstly, we find that a sponsor's capabilities make delegation less-not morelikely. Our empirical analysis shows that a sponsors' capabilities have a significant positive effect on the likelihood of orchestration. In contrast, research on indirect governance expects governors to compromise on hierarchical control when "a 
governor lacks the authority or resources to exercise hard controls." (Abbott et al. 2020a, 624) The underlying assumption is that "weak governments often have little alternative to orchestration" (Abbott et al. 2020a, 624). Similarly, existing scholarship on rebel support assumes - in line with PA Theory - that a support relationship only lacks strong control if the sponsor falls short of the necessary capabilities to exercise it (Byman and Kreps 2010, 9; Salehyan 2010, 505; Salehyan, Gleditsch, and Cunningham 2011, 711).

Our results imply that sponsors' greater capabilities - besides goal alignment and competition-might render "hands-on" control expendable. Compared to weaker states, great powers are in a better position to afford efficiency losses due to rebels' partially non-compliant behavior. At the same time, the risks of delegation-losing local legitimacy and domestic or international backlash - are independent from a sponsor's capabilities. Powerful states might thus accept the inefficient use of their resources while tapping into the benefits of orchestration as the utility exceeds its relative costs. Powerful states might also be less concerned about rebels turning against them (see Bapat 2012). Finally, great powers might be in an advantaged position to weaker states as their overall power projection capabilities render the threat of sanctions more credible than those of weaker states. Powerful sponsors can thus orchestrate rebels in a regional or even global "shadow of hierarchy" which substitutes "hands-on" control instruments (cf. Miller 2005, 210). Sponsors with greater capabilities might be generally more able and willing to tap into the benefits of "hands-off" orchestration.

Secondly, we find that sponsors' choice between orchestration and delegation is significantly stable - and not unstable - over time. Figure 6 presents the effect of years since last orchestration on the probability of a support relationship being orchestrated based on the cubic polynomials of time from Model 1. It shows how the probability of orchestration changes depending on whether a support relationship was previously inactive or orchestrated (Years since Orchestration $=1$ ) or delegated (Years since Orchestration $>1$ ). Figure 6 indicates that the mode of support is remarkably stable. We thus observe a very low probability of a support relationship to change its mode to orchestration when delegation took place in the year before, and vice versa. In other words, while sponsors might change the level of support provided to rebels within a given support mode, they tend to stick to their initially chosen mode of indirect governance. This observed stability of a sponsor's choice between orchestration and delegation presents a challenge to recent scholarship on indirect governance which expects that indirect governance relationships are characterized by "endogenous instabilities" that "can upset the balance on which the initial choice of governance mode was based, leading to dissatisfaction, modifications within modes, shifts between modes, or the complete breakdown of indirect governance" (Abbott et al. 2020a, 629).

Path-dependence might thus be at work within the two modes of indirect war. Indeed, historical-institutionalist approaches would suggest that governance arrangements are characterized by endogenous stability over time due to increasing 


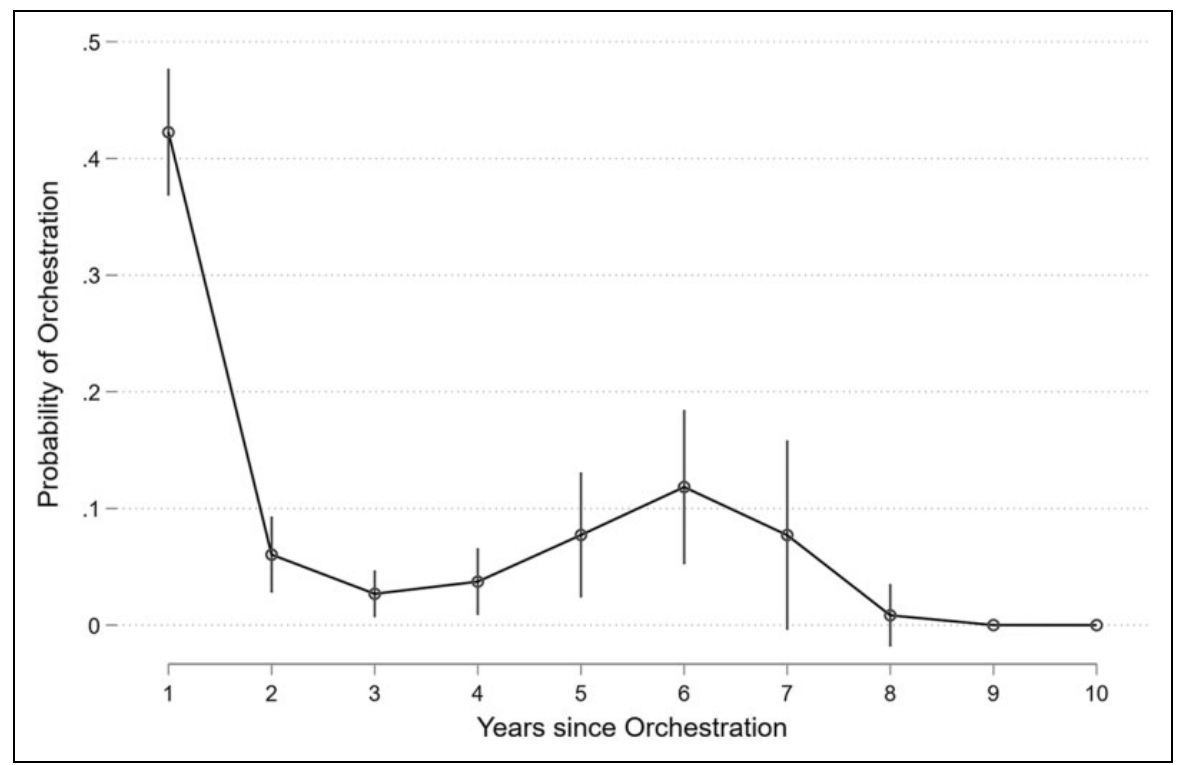

Figure 6. The effect of time since last orchestration on orchestration. Note: Predicted probabilities computed from Model I (95 percent $\mathrm{Cls}$ ) while holding all other variables at their observed values.

returns, socialization, and other positive feedback effects (see, Hall and Taylor 1996; Pierson 2004; Fioretos 2011; Weiss and Heinkelmann-Wild 2020). For instance, in delegation relationships, a rebel group might, over time, specialize its income to the sponsor's support while losing support among the local population. While this is effective in terms of financing, a lack of local legitimacy, in turn, renders switching to orchestration unattractive for the sponsor. Furthermore, given the visibility of delegation, it might be politically costly for a sponsor to back down from publicly supporting a rebel group as this would signal weakness and a lack of commitment (Bapat 2012). Moreover, as orchestration allows rebels to increase their independent capabilities and gain leverage vis-à-vis their sponsor, it gets more and more difficult for the governor to impose hierarchical control on them (see also, Abbott et al. 2020a, 2020b). So even if rebels use these increased capabilities to pursue their own goals, sponsors might prefer to either live with some non-compliance by their intermediary and continue enjoying the benefits of orchestration (or to end the support relationship) instead of shifting from orchestration to delegation.

In this paper, we introduced an indirect governance perspective to explain sponsors' choice between support modes. However, this can only constitute a first step towards understanding the dynamics of indirect governance in rebel support. Future research could add complexity to our parsimonious model of the drivers of orchestration and delegation. Future studies could unpack the time-dependent dynamics of 
indirect warfare and examine why sponsors often stick to their initial support mode. Do support relationships constitute efficient equilibria or are other mechanisms at work that reinforce the chosen mode of support (see, e.g., Weiss and HeinkelmannWild 2020)? Moreover, while our paper focused on the control opportunities enabled or constrained by different support types, future research could examine how powerful states' capacities allow them to issue credible threats to induce rebels' compliance while tapping into the benefits of "hands-off" orchestration. In addition, future studies could also assess how different rebel group characteristics affect support modes. ${ }^{15}$ As San-Akca (2017) has demonstrated that rebels are not simply passive receivers of support, but can actively shape support relationships, rebels might, for instance, choose to reject specific types of support - and the attached strings (see also, Salehyan 2010; Salehyan, Gleditsch, and Cunningham 2011; Bapat 2012). Are rebels more likely to reject "hands-on" delegation than "hands-off" orchestration? Furthermore, a rebel group's fragmentation might also impact state sponsors' choice of support mode. Rebel group fragmentation was demonstrated to induce information and commitment problems, rendering such groups more difficult bargaining partners but also more likely to obtain concessions (K. G. Cunningham 2011, 2013, 2014). Fragmentation might provide sponsors the possibility to manage rebels by an intra-group competition mechanism as they can (threaten to) shift resources to factions if the leadership fails to comply (Tamm 2016). Future research might therefore study whether fragmented groups are more or less likely to receive support without "hands-on" control attached.

Future research could also examine the consequences of orchestration and delegation. Future studies could empirically test our theoretical assumptions underlying the conceptual distinction between "hands-off" orchestration and "hands-on" delegation (see, e.g., Mehrl and Heinkelmann-Wild 2020). Does "hands-on" delegation render rebels' non-compliance less likely? Does "hands-on" delegation lead to increased efforts on the battlefield while "hands-off" orchestration leads rebels to redeploy resources to other objectives besides defeating the target state? Does "hands-off" orchestration shield state sponsors from domestic and international backlash? Does "hands-on" delegation harm rebels' local legitimacy while "hands-off" orchestration leaves it intact or even increases it?

Finally, future researcher could unpack the indirect governance chain by not only considering the relationship between the state sponsor and the rebels, but also the relationship between rebel leadership and their soldiers (see, e.g., Weinstein 2005; Hoover Green 2016) as well as interactions between the different links in this chain (see, e.g., Mehrl 2020, 2021). Future studies could also examine the impact of support modes on group cohesion (see also, Tamm 2016; K. G. Cunningham 2013). Does "hands-off" orchestration provide leadership advantages or disadvantages vis-à-vis their soldiers, and thus affect fragmentation? Such studies might then consider feedback effects between rebels' internal group dynamics and their relationship with state sponsors. 
Overall, while there are ample avenues along which future research can build on and add to our model of indirect governance at war, our key message stands that scholarship on indirect warfare should account for state sponsors' diverging control opportunities over rebel groups and that more control is not always the preferable option.

\section{Conclusion}

In this paper, we theoretically developed and empirically tested a model of indirect governance at war. Drawing on recent scholarship on indirect governance, we suggested differentiating two modes of support relationships in indirect wars: delegation, which allows for the "hands-on" control of rebels' compliance but tends to harm their local legitimacy and to attract responsibility attributions to the sponsor; and "hands-off" orchestration, which allows sponsors to tap into rebels' local legitimacy and enjoy plausible deniability, but diminishes their opportunities to detect and enforce rebels' compliance. This trade-off then shapes sponsors' choice between the two modes. Sponsors prefer orchestration when a lack of hierarchical control is alleviated by the availability of a rebel group with shared ethnic ties (goal alignment thesis) or alternative rebel groups (supply thesis). Sponsors prefer delegation when the conflict is highly salient for them due to long-term rivalry with the targeted state (saliency thesis). The empirical analysis corroborated our model of indirect warfare. As expected, orchestration is more likely to be chosen when the sponsor and the rebel group share ethnic ties and the supply of potential receivers is high. In contrast, we do find some evidence that supporters are more likely to invest in hierarchical control when a conflict is highly salient as implied by the existence of a long-term rivalry, but these results lack robustness.

Our paper contributes to both scholarship on indirect governance as well as rebel support. Conceptually, we go beyond the rebel support literature's focus on delegation by differentiating between orchestration and delegation. This avoids the risk of overstretching the delegation concept and allows analyzing sponsors' choice between different support modes. Moreover, the conceptual distinction between orchestration and delegation might offer a fruitful theoretical foundation for recent studies that explore the varying consequences of different forms of rebel support and financing (Karlén 2017; Sawyer, Cunningham, and Reed 2017; Belgioiso 2018; Haer, Faulkner, and Whitaker 2020). Theoretically, we introduce the indirect governance perspective to peace and conflict studies to explain sponsors' choice between support modes. ${ }^{16}$ Empirically, our paper thereby puts the indirect governance framework to a statistical test. While our theoretical model is largely corroborated by the analysis, we also made two observations that deviate from common expectations: a sponsor's capabilities make delegation less (not more) likely; and sponsors' choice between orchestration and delegation is stable (and not unstable) over time. These insights might inspire further theorizing on the drivers and dynamics of indirect governance. 


\section{Acknowledgments}

We wish to thank the two anonymous reviewers, the editor, as well as Zorzeta Bakaki, Margherita Belgioioso, Felix Biermann, Tobias Böhmelt, Daina Chiba, Kristian Skrede Gleditsch, Vytautas Jankauskas, Brian Philips, Laura Seelkopf, Duncan Snidal, Henning Tamm, and Bernhard Zangl for their helpful comments. A previous version of this paper was presented at the sixtieth Annual Convention of the International Studies Association (ISA) in Toronto, March 2019. We would also like to thank Nadia El Ghali and Louisa Klein-Bölting for excellent research assistance.

\section{Declaration of Conflicting Interests}

The author(s) declared no potential conflicts of interest with respect to the research, authorship, and/or publication of this article.

\section{Funding}

The author(s) received no financial support for the research, authorship, and/or publication of this article.

\section{ORCID iD}

Tim Heinkelmann-Wild (D) https://orcid.org/0000-0003-2699-6048;

Marius Mehrl (D) https://orcid.org/0000-0002-5825-9256.

\section{Supplemental Material}

Supplementary material is available for this article online.

\section{Notes}

1. For the purpose of this paper, we define indirect warfare as instances where a third-party government (i.e., the sponsor) intentionally supports a rebel group (i.e., the receiver) in its fight against its government (i.e., the target) (see Loveman 2002, 30; Salehyan 2010, 494; Mumford 2013, 11). As our focus is on intentional support, for the purposes of this paper, indirect warfare does not include unintentional forms of "de facto" support, that is, instances where rebel groups operate within a third-party state without that state's knowledge or acquiescence such (San-Akca 2016).

2. We take the terms orchestration and delegation from the literature on indirect governance, where delegation refers to hard-controlled, hierarchical relationships and orchestration to soft-controlled relationships between a governor and an intermediary (Abbott et al. 2016, 2020a, 2020b).

3. Our focus is on how support types constrain or enable control. We therefore assume that state sponsors will take advantage of the control opportunities posed by the respective support types.

4. To be sure, we do not claim that orchestration is the main driver of a rebel group's local legitimacy, which is shaped, inter alia, by whether a rebel group extracts resources from the population and mistreats civilians, or provides social services to them (see, e.g., Flynn and Stewart 2018; Lyall, Blair, and Imai 2013). We suggest that, all else equal, "hands- 
off" orchestration is less likely to create the impression of being a foreign power's puppet (see also, Tamm 2020). This not only allows the rebel group to foster its legitimacy by using the received support to succeed in its fight against the target government, but, in the absence of "hands-on" control, also to redeploy it to its own purposes by distributing money or goods among the local population (see Sawyer, Cunningham, and Reed 2017).

5. This parallels with insights from scholarship on the relationship between the rebel leadership and their soldiers, which inter alia examines how rebel leaders screen recruits (Weinstein 2005) and maintain control over their rank-and-file membership (Hoover Green 2016).

6. While among the other rebel groups in a conflict some might adhere to an ideology or pursue goals which diverge from those of the sponsor, rendering them a less attractive and plausible outside option, we hold that a common enemy (i.e., the target government) is sufficient for rebels and a state sponsor to potentially enter into a support relationship. For instance, both Greece and Iran have provided support to the PKK's fight against the Turkish government but are unlikely to have had much sympathy for the group's leftist ideology or a significant interest in the establishment of an autonomous Kurdish state, especially as Iran itself has been facing an insurgency by the Kurdish Democratic Party of Iran.

7. Publicly known support relationships to rebel groups may even be meant as signaling credible commitment to a political cause as argued by Bapat (2012) with regards to the Iranian government's support of Hamas.

8. This support type mainly comprises the transfer of "non-weaponry and non-munition supplies that $[\ldots]$ serve direct military purposes" (Croicu et al. 2011, 16).

9. Relationships involving POLISARIO were originally counted twice for the years 1976 to 1978 due to POLISARIO fighting both Morocco and Mauritania. To avoid doublecounts, we dropped the Mauritanian cases as the conflict with Morocco was the more durable one. In twenty-one instances, it was impossible to code a support dyad as it included only support of an unknown or other type.

10. We account for the TSCS structure of our data in two ways. We set observations of orchestration that do not mark the onset of a previously inactive support relationship or a change in its type to missing because we want to examine why some sponsors choose one type of support instead of the other - and the reasons for doing so may be different from leaving the support mode unchanged (Beck, Katz, and Tucker 1998; McGrath 2015). Moreover, we account for time dependency by including cubic polynomials of the time between the last Orchestration event and the current observation (Carter and Signorino 2010) and cluster standard errors on the support-dyad.

11. Summary statistics are reported in the Online Appendix.

12. This implies that while dropping coup risk, rivalry, and the number of rebel groups increases the sample size and temporal coverage of our models, it also reduces model quality.

13. This effect is conditioned, but always positive and significant, by direct contiguity between sponsor and target state. Ethnic ties increase the probability of orchestration by 10.1 percent if these states are contiguous $(n=152)$ and by 20.1 percent $(n=61)$ if they are not (see Online Appendix). 
14. Table A.2. in the Online Appendix shows the AUC values for all models.

15. On different types of intermediaries in indirect governance, see Abbott et al. (2021) and Jankauskas (2021).

16. Recent contributions have also adopted an indirect governance perspective to study cases of governments' use of militias (Salehyan 2020) and invaders' use of private security companies (Kruck 2020) or local rebels (Tamm 2020) in conflict settings.

\section{References}

Abbott, Kenneth W., Philipp Genschel, Duncan Snidal, and Bernhard Zangl. 2016. "Two Logics of Indirect Governance: Delegation and Orchestration.” British Journal of Political Science 46 (4): 719-29. doi: 10.1017/S0007123414000593.

Abbott, Kenneth W., Philipp Genschel, Duncan Snidal, and Bernhard Zangl. 2020a. "Competence versus Control: The Governor's Dilemma." Regulation \& Governance 14 (4): 619-36. doi: 10.1111/rego.12234.

Abbott, Kenneth W., Philipp Genschel, Duncan Snidal, and Bernhard Zangl, eds. 2020b. The Governor's Dilemma: Indirect Governance beyond Principals and Agents. Oxford, UK: Oxford University Press.

Abbott, Kenneth W., Philipp Genschel, Duncan Snidal, and Bernhard Zangl. 2021. "Beyond Opportunism: Intermediary Loyalty in Regulation and Governance.” Regulation \& Governance. Forthcoming. 1-37.

Allansson, Marie, Erik Melander, and Lotta Themnér. 2017. “Organized Violence, 19892016." Journal of Peace Research 54 (4): 574-87. doi: 10.1177/0022343317718773.

Bapat, Navin A. 2012. "Understanding State Sponsorship of Militant Groups.” British Journal of Political Science 42 (1): 1-29. doi: 10.1017/S000712341100007X.

Beck, Nathaniel, Jonathan N. Katz, and Richard Tucker. 1998. "Taking Time Seriously: Time-series-cross-section Analysis with a Binary Dependent Variable." American Journal of Political Science 42 (4): 1260. doi: 10.2307/2991857.

Belgioiso, Margherita. 2018. "External Non-state Actors' Financial and Military Support and the Portfolio of Killings of Rebel Groups." Paper presented at the Conflict Research Society Conference, University of Birmingham, Birmingham, UK, September $17-18$.

Belkin, Aaron, and Evan Schofer. 2003. "Toward a Structural Understanding of Coup Risk." Journal of Conflict Resolution 47 (5): 594-620. doi: 10.1177/0022002703258197.

Biermann, Felix, and Berthold Rittberger. 2020. "Balancing Competence and Control: Indirect Governance 'Triangles' in EU Regulation." In The Governor's Dilemma: Indirect Governance beyond Principals and Agents, edited by Kenneth W. Abbott, Philipp Genschel, Duncan Snidal, and Bernhard Zangl, 180-202. Oxford, UK: Oxford University Press.

Borghard, Erica D. 2014. "Friends with Benefits? Power and Influence in Proxy Warfare." Dissertation. Accessed May 20, 2021. https://academiccommons.columbia.edu/doi/10. 7916/D8Q81B7Z.

Byman, Daniel. 2005. Deadly Connections. Cambridge,MA: Cambridge University Press. 
Byman, Daniel. 2013. “Outside Support for Insurgent Movements.” Studies in Conflict \& Terrorism 36 (12): 981-1004. doi: 10.1080/1057610X.2013.842132.

Byman, Daniel, and Sarah E. Kreps. 2010. "Agents of Destruction? Applying Principal-agent Analysis to State-sponsored Terrorism.” International Studies Perspectives 11 (1): 1-18. doi: 10.1111/j.1528-3585.2009.00389.x.

Carter, David B., and Curtis S. Signorino. 2010. "Back to the Future: Modelling Time Dependence in Binary Data." Political Analysis 18 (3): 271-92. doi: 10.1093/pan/mpq013.

Cederman, Lars-Erik, Luc Girardin, and Kristian Skrede Gleditsch. 2009. "Ethnonationalist Triads: Assessing the Influence of Kin Groups on Civil Wars." World Politics 61 (3): 403-37. doi: 10.1017/s0043887109000148.

Cederman, Lars-Erik, Kristian Skrede Gleditsch, Idean Salehyan, and Julian Wucherpfennig. 2013. "Transborder Ethnic Kin and Civil War." International Organization 67 (2): 389-410. doi: 10.1017/S0020818313000064.

Cragin, R. Kim. 2015. "Semi-proxy Wars and U.S. Counterterrorism Strategy." Studies in Conflict Terrorism 38 (5): 311-27. doi: 10.1080/1057610X.2015.1018024.

Croicu, Mihai Cătălin, Stina Högbladh, Therése Pettersson, and Lotta Themnér. 2011. "UCDP External Support Project-Disaggregated/Supporter Dataset Codebook, Version 1.0. Uppsala Conflict Data Program (UCDP). Department of Peace and Conflict Research." Accessed May 20, 2021. https://ucdp.uu.se/downloads/extsup/ucdp_external_support_disag gregated_codebook_1.0.pdf.

Cunningham, David E., Kristian Skrede Gleditsch, and Idean Salehyan. 2013. "Non-state Actors in Civil Wars: A New Dataset." Conflict Management and Peace Science 30 (5): 516-31. doi: 10.1177/0738894213499673.

Cunningham, Kathleen Gallagher. 2011. "Divide and Conquer or Divide and Concede: How Do States Respond to Internally Divided Separatists?" American Political Science Review 105 (2): 275-97. doi: 10.1017/S0003055411000013.

Cunningham, Kathleen Gallagher. 2013. "Actor Fragmentation and Civil War Bargaining: How Internal Divisions Generate Civil Conflict." American Journal of Political Science 57 (3): 659-72. doi: 10.1111/ajps.12003.

Cunningham, Kathleen Gallagher. 2014. Inside the Politics of Self-determination. New York: Oxford University Press. doi: 10.1093/acprof: oso/9780199364909.001.0001.

Fioretos, Orfeo. 2011. "Historical Institutionalism in International Relations." International Organization 65 (2): 367-99. doi: 10.1017/S0020818311000002.

Flynn, D. J., and Megan A. Stewart. 2018. "Secessionist Social Services Reduce the Public Costs of Civilian Killings: Experimental Evidence from the United States and the United Kingdom." Research \& Politics 5 (4): 1-10. doi: 10.1177/2053168018810077.

Gleditsch, Kristian Skrede. 2002. "Expanded Trade and GDP Data." Journal of Conflict Resolution 46 (5): 712-24. doi: 10.1177/0022002702046005006.

Gleditsch, Kristian Skrede. 2013. "Expanded Trade and GDP Data." Accessed May 20, 2021. http://ksgleditsch.com/exptradegdp.html.

Groh, Tyrone Lee. 2010. "War on the Cheap? Assessing the Costs and Benefits of Proxy War." Accessed May 20, 2021. https://repository.library.georgetown.edu/bitstream/10822/553084/ 1/grohTyrone.pdf. 
Habyarimana, James, Macartan Humphreys, Daniel N. Posner, and Jeremy M. Weinstein. 2007. "Why Does Ethnic Diversity Undermine Public Goods Provision?" American Political Science Review 101 (4): 709-25. doi: 10.1017/S0003055407070499.

Haer, Roos, Christopher Michael Faulkner, and Beth Elise Whitaker. 2020. "Rebel Funding and Child Soldiers: Exploring the Relationship between Natural Resources and Forcible Recruitment." European Journal of International Relations 83 (1): 236-62. doi: 10.1177/ 1354066119850622.

Hall, Peter A., and Rosemary C. R. Taylor. 1996. "Political Science and the Three New Institutionalisms." Political Studies 44 (5): 936-57. doi: 10.1111/j.1467-9248.1996. tb00343.x.

Harbom, Lotta, Erik Melander, and Peter Wallensteen. 2008. "Dyadic Dimensions of Armed Conflict, 1946-2007.” Journal of Peace Research 45 (5): 697-710. doi: 10.1177/ 0022343308094331.

Heinkelmann-Wild, Tim, and Bernhard Zangl. 2020. "Multilevel Blame Games: Blame-shifting in the European Union." Governance 33 (4): 953-69. doi: 10.1111/gove.12459.

Heinkelmann-Wild, Tim, Bernhard Zangl, Berthold Rittberger, and Lisa Kriegmair. 2021. "How Delegation Shapes Governments' Blame Avoidance Opportunities: The Case of the EU." European Consortium of Political Science (ECPR) Standing Group on European Union (SGEU) $10^{\text {th }}$ Biennial Conference, Rome, Italy, June 10-12.

Hoekstra, Quint. 2021. "Helping the Contras: The Effectiveness of U.S. Support for Foreign Rebels during the Nicaraguan Contra War (1979-1990)." Studies in Conflict \& Terrorism 44 (6): 521-41. doi: 10.1080/1057610X.2019.1568004.

Högbladh, Stina, Therése Pettersson, and Lotta Themnér. 2011. External Support in Armed Conflict 1975-2009: Presenting New Data. Paper presented at the 52nd Annual International Studies Association Convention, Montreal, Canada, March 16-19.

Hoover Green, Amelia. 2016. "The Commander's Dilemma." Journal of Peace Research 53 (5): 619-32. doi: 10.1177/0022343316653645.

Hovil, Lucy, and Eric Werker. 2005. "Portrait of a Failed Rebellion.” Rationality and Society 17 (1): 5-34. doi: 10.1177/1043463105051775.

Jankauskas, Vytautas. 2021. "Delegation and Stewardship in International Organizations." Journal of European Public Policy. Forthcoming. 1-21. doi: 10.1080/13501763.2021. 1883721.

Karlén, Niklas. 2017. “The Legacy of Foreign Patrons." Journal of Peace Research 54 (4): 499-512. doi: 10.1177/0022343317700465.

Klein, James P., Gary Goertz, and Paul F. Diehl. 2006. "The New Rivalry Dataset: Procedures and Patterns." Journal of Peace Research 43 (3): 331-48. doi: 10.1177/ 0022343306063935.

Krieg, Andreas, and Jean-Marc Rickli. 2019. Surrogate Warfare: The Transformation of War in the Twenty-first Century. Washington, DC: Georgetown University Press.

Kruck, Andreas. 2020. "Governing Private Security Companies: Politics, Dependence, and Control." In The Governor's Dilemma: Indirect Governance beyond Principals and Agents, edited by Kenneth W. Abbott, Philipp Genschel, Duncan Snidal, Bernhard Zang, 137-55. Oxford, UK: Oxford University Press. 
Larson, Jennifer M., and Janet I. Lewis. 2017. "Ethnic Networks." American Journal of Political Science 61 (2): 350-64. doi: 10.1111/ajps.12282.

Loveman, Chris. 2002. "Assessing the Phenomenon of Proxy Intervention.” Conflict, Security \& Development 2 (3): 29-48. doi: 10.1080/14678800200590618.

Lyall, Jason, Graeme Blair, and Kosuke Imai. 2013. "Explaining Support for Combatants during Wartime: A Survey Experiment in Afghanistan." American Political Science Review 107 (4): 679-705. doi: 10.1017/S0003055413000403.

Maoz, Zeev, and Belgin San-Akca. 2012. "Rivalry and State Support of Non-state Armed Groups (NAGs), 1946-2001 1.” International Studies Quarterly 56 (4): 720-34. doi: 10. 1111/j.1468-2478.2012.00759.x.

Marshall, Monty G., Ted Robert Gurr, and Keith Jaggers. 2016. "Polity IV Project: Political Regime Characteristics and Transitions, 1800-2015." Dataset Users' Manual. Center for Systemic Peace. Accessed May 20, 2021. http://www.systemicpeace.org/inscr/p4man ualv2018.pdf.

McGrath, Liam F. 2015. "Estimating Onsets of Binary Events in Panel Data." Political Analysis 23 (4): 534-49. doi: 10.1093/pan/mpv019.

Mehrl, Marius, and Tim Heinkelmann-Wild. 2020. "External Support in Civil War: How Sponsors' Control over Rebels Shapes Conflict Dynamics." Annual workshop of the Working Group on Empirical Methods of the German Association for Peace and Conflict Studies, Hertie School Berlin, Germany, September 21-22.

Mehrl, Marius. 2020. "Female Combatants and Wartime Rape: Reconsidering the Role of Women in Armed Conflict." Armed Forces \& Society. Forthcoming. 1-16. doi: 10.1177/ 0095327 X20981696.

Mehrl, Marius. 2021. "The Effect of Child Soldiers on Rebel Violence against Civilians." Civil Wars. Forthcoming. 1-44. doi: 10.1080/13698249.2021.1903780.

Melander, Erik, Therése Pettersson, and Lotta Themnér. 2016. "Organized Violence, 19892015.” Journal of Peace Research 53 (5): 727-42. doi: 10.1177/0022343316663032.

Miller, Gary J. 2005. "The Political Evolution of Principal-agent Models." Annual Review of Political Science 8 (1): 203-25. https://doi.org/10.1146/annurev.polisci.8.082103.104840.

Mumford, Andrew. 2013. Proxy Warfare. Cambridge, UK: Polity.

Petrova, Marina G. 2019. "What Matters Is Who Supports You: Diaspora and Foreign States as External Supporters and Militants' Adoption of Nonviolence." Journal of Conflict Resolution 63 (9): 2155-79. doi: 10.1177/0022002719826645.

Pierson, Paul. 2004. Politics in Time: History, Institutions, and Social Analysis. Princeton, NJ: Princeton University Press.

Popovic, Milos. 2017. "Fragile Proxies: Explaining Rebel Defection against Their State Sponsors." Terrorism and Political Violence 29 (5): 922-42. doi: 10.1080/09546553. 2015.1092437.

Rauta, Vladimir. 2016. "Proxy Agents, Auxiliary Forces, and Sovereign Defection: Assessing the Outcomes of Using Non-state Actors in Civil Conflicts." Southeast European and Black Sea Studies 16 (1): 91-111. doi: https10.1080/14683857.2016.1148416.

Rauta, Vladimir. 2018. "A Structural-relational Analysis of Party Dynamics in Proxy Wars." International Relations 32 (4): 449-67. doi: 10.1177/0047117818802436. 
Reyntjens, Filip. 2001. "Briefing: The Democratic Republic of Congo, from Kabila to Kabila." African Affairs 100 (399): 311-17. doi: 10.1093/afraf/100.399.311.

Saideman, Stephen M. 1997. "Explaining the International Relations of Secessionist Conflicts: Vulnerability versus Ethnic Ties." International Organization 51 (4): 721-53. doi: $10.1162 / 002081897550500$.

Saideman, Stephen M. 2001. The Ties that Divide: Ethnic Politics, Foreign Policy, and International Conflict. New York: Columbia University Press.

Saideman, Stephen M. 2002. "Discrimination in International Relations: Analyzing External Support for Ethnic Groups.” Journal of Peace Research 39 (1): 27-50. doi: 10.1177/ 0022343302039001002.

Salehyan, Idean. 2010. "The Delegation of War to Rebel Organizations." Journal of Conflict Resolution 54 (3): 493-515. doi: 10.1177/0022002709357890.

Salehyan, Idean. 2020. "Militias and the Iraqi State: Shifting Modes of Indirect Governance." In The Governor's Dilemma: Indirect Governance beyond Principals and Agents, edited by Kenneth W. Abbott, Philipp Genschel, Duncan Snidal, Bernhard Zang, 100-18. Oxford, UK: Oxford University Press.

Salehyan, Idean, Kristian Skrede Gleditsch, and David E. Cunningham. 2011. "Explaining External Support for Insurgent Groups." International Organization 65 (4): 709-44. doi: 10.1017/S0020818311000233.

Salehyan, Idean, David Siroky, and Reed M. Wood. 2014. "External Rebel Sponsorship and Civilian Abuse: A Principal-agent Analysis of Wartime Atrocities." International Organization 68 (3): 633-61. doi: 10.1017/S002081831400006X.

San-Akca, Belgin. 2009. "Supporting Non-state Armed Groups: A Resort to Illegality?" Journal of Strategic Studies 32 (4): 589-613. doi: 10.1080/01402390902987012.

San-Akca, Belgin. 2016. States in Disguise. Oxford, UK: Oxford University Press.

San-Akca, Belgin. 2017. "States and Nonstate Armed Groups (NAGs) in International Relations Theory." In the Oxford Encyclopedia of Empirical International Relations Theory, edited by William Thompson. Oxford, UK: Oxford University Press. Accessed May 20, 2021. https://doi.org/10.1093/acrefore/9780190228637.013.303.

Sawyer, Katherine, Kathleen Gallagher Cunningham, and William Reed. 2017. "The Role of External Support in Civil War Termination.” Journal of Conflict Resolution 61 (6): 1174-202. doi: 10.1177/0022002715600761.

Schwarzenbeck, Helena. 2017. Politische Verantwortung: Der Einfluss von GovernanceDesign auf die öffentliche Zuweisung von Verantwortung. [Political Responsibility: The Influence of Governance Design on the Public Attribution of Responsibility.]. BadenBaden, Germany: Nomos.

Singer, J. David, Stuart Bremer, and John Stuckey. 1972. "Capability Distribution, Uncertainty, and Major Power War, 1820-1965." In Peace, War, and Numbers, edited by M. Bruce Russet, 19-48. Beverly Hills, CA: Sage.

Small Arms Survey. 2012. "Reaching for the Gun: Arms Flow and Holdings in South Sudan." HSBA Issue Brief 19. Accessed May 20, 2021. http://www.smallarmssurveysudan.org/ pdfs/HSBA-SIB-19-Arms-flows-and-holdings-South-Sudan.pdf. 
Stearns, Jason. 2013. Banyamulenge: Insurgency and Exclusion in the Mountains of South Kivu. Usalama Project. London, UK: Rift Valley Institute.

Stinnett, Douglas M., Jaroslav Tir, Paul F. Diehl, Philip Schafer, and Charles Gochman. 2002. "The Correlates of War (Cow) Project Direct Contiguity Data, Version 3.0." Conflict Management and Peace Science 19 (2): 59-67. doi: 10.1177/073889420201900203.

Szekely, Ora. 2016. "A Friend in Need: The Impact of the Syrian Civil War on Syria's Clients (a Principal-agent Approach).” Foreign Policy Analysis 12 (3): 450-68. doi: 10.1111/fpa.12069.

Tamm, Henning. 2016. "The Origins of Transnational Alliances: Rulers, Rebels, and Political Survival in the Congo Wars.” International Security 41 (1): 147-81. doi: 10.1162/ISEC_a_ 00252.

Tamm, Henning. 2020. “The Invader's Dilemma: Enlisting Rebel Groups.” In The Governor's Dilemma: Indirect Governance beyond Principals and Agents, edited by Kenneth W. Abbott, Philipp Genschel, Duncan Snidal, Bernhard Zang, 119-36. Oxford, UK: Oxford University Press.

Todisco, Claudio. 2015. "Real but Fragile: The Greater Pibor Administrative Area." HSBA Working Paper 35. Accessed May 20, 2021. http://www.smallarmssurveysudan.org/filead min/docs/working-papers/HSBA-WP35-Greater-Pibor.pdf.

Tull, D. M. 2003. "A Reconfiguration of Political Order? The State of the State in North Kivu (DR Congo)." African Affairs 102 (408): 429-46. doi: 10.1093/afraf/adg046.

Vogt, Manuel, Nils-Christian Bormann, Seraina Rüegger, Lars-Erik Cederman, Philipp Hunziker, and Luc Girardin. 2015. "Integrating Data on Ethnicity, Geography, and Conflict." Journal of Conflict Resolution 59 (7): 1327-42. doi: 10.1177/0022002715591215.

Ward, Michael D., Brian D. Greenhill, and Kristin M. Bakke. 2010. "The Perils of Policy by P-value: Predicting Civil Conflicts.” Journal of Peace Research 47 (4): 363-75. doi: 10. $1177 / 0022343309356491$.

Weinstein, Jeremy M. 2005. "Resources and the Information Problem in Rebel Recruitment." Journal of Conflict Resolution 49 (4): 598-624. doi: 10.1177/0022002705277802.

Weiss, Moritz, and Tim Heinkelmann-Wild. 2020. "Disarmed Principals: Institutional Resilience and the Non-enforcement of Delegation." European Political Science Review 12 (4): 409-25. doi: 10.1017/S1755773920000181. 